\title{
Gendered Effects of Home-Based Work on Parents' Capability to Balance Work with Non-work: Two Countries with Different Models of Division of Labour Compared
}

\author{
Anna Kurowska ${ }^{1}$ (D)
}

Accepted: 9 November 2018 / Published online: 30 November 2018

(c) The Author(s) 2018

\begin{abstract}
This paper explores gendered impact of home-based work (HBW) on the capability to balance work with non-work in double-earner families with dependent children in two countries with distinct models of division of labour: Poland and Sweden. At first, I critically engage with the WLB conceptualization in HBW studies and try to address identified gaps. Driving from the theoretical concept of 'burden of responsibilities' and setting it in the capability approach, I propose to operationalize the capability to balance work with nonwork as a latent construct, observed through two indicators of the burden of unpaid work responsibilities related to one's engagement in paid work. To simultaneously measure this capability as a latent construct and the impact of HBW on this capability, I estimate a simple structural equation model for each country. The results show that men in both countries have higher capabilities to balance work with non-work than women, but the difference between genders is smaller in Sweden. I also find that HBW is related to lower capability to balance work with non-work for mothers in both countries and for fathers in Sweden only. The results of this study show that in a relatively gender equal society (Sweden) the negative impact of home based work on the capability to balance work with non-work affects both genders. On the contrary - in a more traditional society (Poland), men are able to 'escape' the trap of double burden of paid and unpaid work when working from home while women do not.
\end{abstract}

Keywords Telework - Work-family reconciliation · Work-life balance $\cdot$ Capability approach $\cdot$ Gender roles $\cdot$ Unpaid work $\cdot$ Exploitation model

\section{Introduction}

In recent years there has been renewed interest in the concept of home-based work, with its potential to offer workplace flexibility (Powell and Craig 2015). Between 2006 and 2016, the share of people working from home ('usually' or 'sometimes') in the EU rose

Anna Kurowska

a.kurowska@uw.edu.pl

1 Institute of Social Policy, University of Warsaw, Nowy Świat 67, room 110, 00-927 Warsaw, Poland 
by $21.3 \%$, representing $14.8 \%$ of the total employed population in the region (Eurostat 2017a). Similar trends have been observed in other developed countries. For example, in the US between 1999 and 2010 the incidence of home-based work increased by $18 \%$, with the largest increase occurring between 2005 and 2010 (from 7.8 to 9.5\%) (Mateyka et al. 2012).

There are numerous definitions of home-based work (also termed homeworking - see e.g. Felstead et al. 2002). Following Crosbie and Moore (2004) I define the term broadly as any paid work carried out predominantly from home, regardless of the type of work. While home-based work is sometimes used as a synonym for telework, the latter term is broader, relating as it does to "working from anywhere", and not necessarily from home (see Morganson et al. 2009; Kurland and Bailey 1999; Hislop and Axtell 2007). Some authors also use home-based work as a synonym for un-paid (non-market) work at home (see Craig and Sawrikar 2009). However, since this may confuse readers, I have not used this terminology in this article.

It is argued that home-based work (HBW) enables workers to achieve work-life balance (WLB) by making it easier to juggle work and family responsibilities and to have more time for family and leisure, as there is no need to commute to work (see e.g. Powell and Craig 2015; Crosbie and Moore 2004; Felstead et al. 2002). However, some authors show that this is not always the case (see e.g. Wight and Raley 2009) while others have found that working from home comes with its own set of negative implications. For example, it strengthens the permeability of the boundary between work and family (by e.g. enabling multitasking), thus increasing tensions between work and family schedules (e.g.; Hartig et al. 2007; Marsh and Musson 2008; Russell et al. 2009; Sullivan and Lewis 2001; van der Lippe and Lippényi 2018). Furthermore, it increases the amount of time women, in contrast to men, spend on housework and childcare, thereby strengthening/reproducing gender roles (Sullivan and Lewis 2001; Hilbrecht et al. 2008; Kim 2018; Chung and Van der Lippe 2018). The ambiguous effects HBW seems to have on women's work-life nexus/interference call for further research into the adequacy of the conceptualizations and measurements used to establish what 'work' is in the concept of WLB as it is applied in research on HBW.

Home-based work enables the individual to perform work and childcare or housework activities in the same place and, to a significant extent, at the same time. The boundary between the two spheres (paid and unpaid work) is not always clear and thus the definition of balance between the two, from an objective perspective, encompasses neither. Furthermore, it has been argued that the way paid and unpaid work are interwoven, when one is working from home, is gendered. Women tend to integrate these two spheres by adopting a polychromous time structure, while men are more monochromic in their use of time (see Hilbrecht et al. 2008; Sullivan and Lewis 2001). This article seeks to contribute to this literature. First, I discuss the ways previous studies link the positive and negative effects of HBW to WLB. I discuss the caveats of some of the current conceptualizations of WLB in HBW research, particularly the non-inclusion of unpaid work in the work-side of the work-life nexus. I then propose an analytical framework that can be used to measure a particular aspect of work-life balance: individuals' capability to balance work with non-work. 'Capability' here refers to having not only enough time, but also enough physical and psychical energy to engage in non-work activities while maintaining a given level of paid and un-paid work responsibilities. Finally, I apply the proposed concept on representative samples of working mothers and fathers with dependent children in two countries with different models of labour division between genders: Poland and Sweden. I explore whether the capability to balance work with non-work differs by gender and whether both the gendered 
division of this capability, as well as the gendered impact of HBW on this capability differ in both countries (i.e. in two distinct contexts of models of the division of labour).

\section{Theoretical Background}

There is an abundance of studies on the impact of HBW on WLB (see e.g. Aguilera et al. 2016; Morganson et al. 2009; Maruyama et al. 2009; Hilbrecht et al. 2008; Hislop and Axtell 2007; Crosbie and Moore 2004; Sullivan and Lewis 2001; Lott 2018; van der Lippe and Lippényi 2018; Kim 2018; Chung and Van der Lippe 2018). In some of these studies, HBW is implicitly, and sometimes explicitly (Felstead et al. 2002; see also Gregory and Milner 2009) conceptualized as a work-life balance practice. Some supporters of the so-called 'new opportunities for flexibility model' stress that HBW provides workers with more time and flexibility to engage with other (non-work) spheres of life, and therefore increases work-life balance (Huws et al. 1990). In these studies, inherent characteristics of home-based work (or its immediate/natural consequences) are interpreted as positive effects of HBW on WLB 'by definition'. Such characteristics include more time being available for non-work tasks thanks to the lack of a need to commute as well as the flexibility of time schedules. As a result, the demarcation between the dependent and independent variables in the discussion on the relationship between HBW and WBL isn't clear. ${ }^{1}$ It is also important that in the literature, it is almost exclusively paid-for work that is referred to as 'work', while 'life' stands for 'everything that lies outside the realm of formal paid employment, but which falls inside the realm of family or home' (Ransome 2007: 377). Less time spent on paid work means there is more time for 'life', and thus it is evaluated as one of the positive outcomes of HBW (Fleetwood 2007).

The simple division between paid 'work' and 'life' has come in for considerable criticism in the WLB literature (see e.g. Bradley et al. 2005; Glover 2002; Lewis 2003; Pettinger et al. 2005; Taylor 2002, 2004; Ungerson and Yeandle 2005; Ransome 2007; Pichler 2009). The major problem with this division, particularly in the context of HBW research, is that it underestimates un-paid work undertaken at home (i.e. cooking, cleaning, caring for children) which, in most countries, is predominantly carried out by women. Some studies even explicitly equate work-life balance with work-family balance. For example, Gajendran and Harrison (2007) equalize the lack of work-life balance to work-family conflict. Therefore, in some of these studies, 'life' for women is thought to consist of familyrelated duties, mirroring the concept of 'women's ethics of care', while little attention is paid to other spheres of women's lives (for a similar critique see also Pichler 2009).

Many other studies, however, already point out the different allocations of the 'life' sphere, and provide a gender sensitive analysis of WLB. Several time-use studies of the impact of HBW provide evidence that women, in contrast to men, tend to reallocate the additional time 'saved' from not having to commute to additional caregiving or housework rather than to leisure (Powell and Craig 2015; Wheatley 2012; Hilbrecht et al. 2008; Clawson and Gerstel 2014). Hilbrecht et al. (2008: 474) stress that HBW is 'not optimal in terms of work-life balance' for women, because, according to their study, 'the spheres of work

\footnotetext{
1 This adds to another general criticism of WLB operationalization that Pichler (2009) describes as 'mixing cause and effect'. He points at particular wording in questions in large-scale surveys, as e.g. the European Social Survey, which suggests the explanations for work-life conflicts; as a remedy, Pichler suggests reformulating them.
} 
and care greatly outweigh personal time, even though personal leisure was valued by at least some women'. This is predominantly due to culturally defined gender role and lifecycle expectations that leave little room for leisure pursuits among women (Hilbrecht et al. 2008). This is conceptualized as part of the 'exploitation model', in which home-based work is viewed as perpetuating the exploitation of women in terms of both paid work and unpaid work (Huws et al. 1990; Sullivan and Lewis 2001). These impacts, however, are interpreted as negative side effects of the achievement of work-life balance among women rather than considered as part of the conceptualization and measurement of WLB or the lack thereof. For example, Sullivan and Lewis conclude that 'teleworking can simultaneously enhance work-life balance while perpetuating traditional work and family roles' (2011, p. 123). In most studies care-time is not perceived as part of (un-paid) work engagement, and therefore the burden of childcare and housework tasks are not comprehensively taken into account for the 'work' side of the work-life nexus.

In my study I follow the theoretical approach proposed by Ransome (2007: 374), who clearly treats paid and unpaid work as one side of the work-life realm (though he has not yet applied his idea empirically). He argues that when talking about WLB 'we need to start out from a much more sophisticated conception' of what he calls 'the total responsibility burden of households'. He explicitly classifies unpaid work, together with paid work, as a kind of 'necessary work' which has extrinsic, practical outcomes, and is to a large extent characterized as objective and imposed. The 'rest', i.e. the non-work, regardless of whether the 'work' that one engages in is paid or unpaid, pertains to what Ransome calls 'recreational labour' and describes as 'intrinsic, subjective and voluntary' (Ransome 2007: 374). Here 'recreational labour' refers to any activity not considered to be 'necessary work'. This implies that 'recreational labour' refers not only to 'leisure, pleasure and enjoyment' but also to such elements of 'personal time' as 'sleep, meals, self-care and relationships' (Ransome 2007: 378; see also Ungerson and Yeandle 2005: 248).

Even if such areas of labour as housework and childcare are not entirely imposed and non-voluntary, to a large extent they consist of tasks that he or-much more often-she is expected to do (or have done) and which comprise necessary, routine duties. Therefore, building on Ransome, I assume that it is not only paid (formal) work that constrains the time and energy that we can engage in non-work (or, in Ransome's words, in 'recreational labour'), but also the unpaid work done within the household.

Capturing 'the burden of responsibilities', not simply time spent on (un)paid work, is of crucial importance. Although it does provide some insight, time allocation does not fully reflect the allocation of responsibilities, i.e. the overall burden of being a parent and/or a housewife. Several studies show that while men spend more time with children than they did decades ago, mothers still shoulder the 'worrying' and 'caring' about children's welfare (including their physical and mental development) (see e.g. Craig and Bittman 2008; Bianchi et al. 2006; Presser 1994; Zick and Bryant 1996). Offer and Schneider (2011) show that mothers spend more hours a week multitasking than fathers, a fact mainly attributable to time spent on housework and childcare. Furthermore, mothers tend to be more involved than fathers in labour-intensive chores (Milkie and Peltola 1999; Twigges et al. 1999). Therefore, comparisons of the total workload resulting from adding time spent on paid and unpaid work for mothers and fathers may be misleading, underestimating the 'exploitation' effect of home-based work. Furthermore, in case of HBW, un-paid work (housework or childcare) may be woven into the time spent on paid-work, making it more exhausting. Thus, the time spent on one and the other may be difficult to disentangle. This article adds to the literature as it aims to measure the 'responsibility burden' of unpaid work, and not simply time spent on it. 
Apart from Ransome's 'responsibility burden' approach (2007), I also refer to the way Hobson and others (Hobson 2014²; Hobson et al. 2011; Yerkes and den Dulk 2015) conceptualize the balance between work and non-work, by setting it in Amartya Sen's (1999a) capability approach. I conceptualize the balance between necessary work and non-work as a 'valued functioning' and focus on capturing the 'capability' to achieve this 'valued functioning', which is described in detail in the next section. To be precise, the next section proposes an analytical framework to measure the capability to balance work with non-work based on Ransome's concept of the 'burden of responsibilities' but reframed in the capability approach perspective.

\section{Analytical Framework}

The framework I propose relies on a more 'objective' approach to the conceptualization and measurement of work-life balance, contrary to earlier WLB studies, which prevailingly employ the 'subjective' approach (see a review by Casper et al. 2017). The latter is usually based on the individuals' responses to questions about perceived WLB or lack thereof (e.g. the frequency of negative experiences connected to the fulfillment of responsibilities in one sphere due to the obligations arising from the other; see Peters et al. 2009) or scale-based perceptions of work-life balance/conflict or satisfaction (Hilbrecht et al. 2008; Fagan and Press 2008; Silver 1993). Apart from being focused only on paid work, this also has another important shortcoming. Gender differences in the individual's perceptions of work-life conflict may be underestimated due to 'adaptive preferences' (Sen 1999b). As Sen (1999b) argues, women, having adapted to the double burden of working and being responsible for childcare and housework, may underestimate their work-life imbalance compared to men in similar situations. As the author argues, we thus should not (only) rely on the individual's subjective evaluations but try to more objectively measure his/her capabilities, i.e. his/her ability to achieve certain valued functionings. The latter refer to those 'doings' or 'beings' that people 'have reason to value' (Sen 1999a). Sen underlines that 'valued functionings' should not be confused with individual (subjective) preferences, and rather refer to fundamental/intrinsic or at least widely shared values within a certain society. Unlike Nussbaum, however, Sen does not provide a list of such valuable functionings or related capabilities.

In this study I refer to one of today's highly 'valued functionings', i.e. balancing work with non-work (Hobson 2014), but conceptualized with the use of Ransome's categories (2007) of 'responsibility burden', 'necessary work' and 'recreational labour'. I conceptualize the capability of an individual to engage in recreational labour-that is, the capability of an individual to balance work with non-work-as a latent, non-observable concept. In the CA framework, the capabilities are conceptualized as multidimensional, theoretical constructs of which we can only observe certain indicators, reflecting the (non)achievement of particular (valued) functionings (Sen 1999a; see also Addabbo et al. 2014). In this study, therefore, the capability to balance work with non-work is conceptualized as an abstract, unobservable, latent construct, which is mirrored in individuals' engagement in 'necessary labour', including paid as well as unpaid work within

\footnotetext{
2 This is a similar assumption to the one by Hobson (2014), however I see both paid and unpaid work as constraint in terms of work-life balance.
} 
the household, i.e. his/her 'burden of responsibilities'. This burden of responsibilities reflects one's ability or inability to engage in recreational labour, i.e. to balance work with non-work. Unpaid work within the household includes housework (cleaning, washing the dishes, maintenance, household accounting) and childcare-related tasks (feeding children, putting them to bed, driving them to school, preparing meals for them). It may be argued that spending time with children has elements of 'necessary work' and 'recreational labour'. Therefore, it would not be appropriate to conceptualize the child-related unpaid work engagement in terms of time spent on childcare (or with kids) in general. In order to disentangle child-related 'necessary labour' from leisure and emotional time spent with children ('recreational labour'), the operationalization of childcare-related unpaid work applied in this study refers only to the engagement in the necessary, routine types of unpaid work, such as feeding children, dressing them up or driving them to (pre)school.

Moreover, I respect Ransome's suggestion that WLB should not be conceptualized in dualistic terms as achieving or not achieving 'balance'. I allow for a gradable way of assessing the capability to balance work with non-work, from 'little capability' to 'full capability'. I assume that the higher the total amount of 'necessary work-'related responsibilities, the lower one's capability to engage in 'recreational labour' i.e. to balance work with non-work. For example, if a mother works full time and she is the only one responsible for housework and/or childcare tasks, she lacks the capability-in terms of time and physical and psychological capacity, both of which are limited commodities - to engage in non-work activities. What may increase her capability to engage in non-work is outsourcing and/or sharing housework and childcare duties with others (e.g. partner) and/or lowering her engagement in paid-work. In the proposed framework, home-based work has the potential to positively impact one's capability to balance work with non-work because it creates the opportunity to decrease engagement in 'necessary labour' (by circumventing the commute and enabling more flexible scheduling of paid work and family responsibilities). At the same time, however, it may result in higher engagement in un-paid work and thus negatively impact the capability to engage in non-work activities. It could, of course, also increase engagement in paid work. But in this framework that would not mean greater balance between work and non-work. As Pichler (2009) and Hobson (2014) point out, the mainstream WLB debates tend to focus on long working hours as the most likely threat to a balanced life. That is why, in my framework, I focus on the capability to do something else than paid and unpaid work, i.e. recreational labour. I also focus on the fact that working mothers and fathers find it difficult to achieve non-work activities (such as leisure) particularly due to childcare responsibilities.

Finally, following Ransome (2007), I assume that work-life balance in households should not be described in terms of one 'ideal type', e.g. the one in which both parents share paid and unpaid work equally. Thus, I do not assume any proportions of paid and un-paid work to be ideal (optimal). However, I assume that the higher the total burden of responsibilities issuing from both paid and un-paid work, the lower the capability to engage in non-work activities, i.e. a lower capability to balance work with non-work. In other words, the work versus non-work balance is a balance between all the necessary 'work', which includes both paid and unpaid work, and non-work (i.e. 'recreational labour' in Ransome's words). In this frame, the composition of 'work' is allowed to vary because it builds on the underlying assumption that different families may have different preferences about that division of labour. Nevertheless, it is assumed that all individuals need to balance 'necessary work' with 'recreational labour' and that the more they engage in 'necessary work', the less able they are to balance it with 'recreational labour'. 


\section{The Choice of Countries for Empirical Analyses and Hypotheses}

The analytical framework proposed deals with the gendered division of labour in order to analyze the impact of home-based work on the capability of men and women to balance work with non-work. I chose Poland and Sweden, two countries that vary significantly in terms of their gendered division of labour.

In Poland, it is mainly women who are the primary (and often the only) care-givers (Gilligan 1982; Mcdowell 2004). At the same time, women also have a relatively high labour force participation rate (employment rate among women aged 20-49 in 2016 was $73.7 \%$, slightly above the EU average). According to Eurostat (2017b), the difference in the total amount of paid and unpaid working hours for women and men in 2016 in Poland was $21.6 \%$. Women in Poland worked on the labour market an average of only $4 \mathrm{~h}$ less than men (36 and $40 \mathrm{~h}$ accordingly), but they did over three times more unpaid work than men did (18 and $5 \mathrm{~h}$, respectively). This makes Poland a good example of the male breadwinner model (Ciccia and Bleijenbergh 2014), in which men are perceived as the main breadwinners and women as the main housekeepers and caregiver for children, even if they are also very actively engaged in paid work. Fathers in Poland, by contrast, are not expected to share the unpaid work at home, even when both parents are in paid employment (Voicu et al. 2008; Knudsen and Wærness 2008; Kurowska 2013). Therefore, I expect mothers living in double earner households (i.e. where both mothers and fathers work) in Poland to be less capable of balancing work with non-work than fathers living in such households (Hypothesis 1). I further expect that HBW would be associated with lower capability among mothers (Hypothesis 2), due to their double duty, but not among fathers (Hypothesis 3), as working men in Poland tend not be expected to engage in housework and childcare tasks when they are in paid employment.

Sweden, on the other hand, is known for having one of the highest gender equality levels in Europe (Ciccia and Bleijenbergh 2014; Mencarini and Sironi 2010). For several decades, men have been encouraged to share the unpaid work with women (Allard et al. 2007). Sweden is classified as a 'supported universal breadwinner model' and one of the European countries closest to the 'universal caregiver model' (Ciccia and Bleijenbergh 2014) or 'dual carer model' (Korpi et al. 2013). According to Eurostat (2017b) the difference in the total amount of paid and unpaid hours among women and men is $4.9 \%$. Women in Sweden work on the labour market an average of $3 \mathrm{~h}$ less than men (37 and $40 \mathrm{~h}$, respectively), and do seven more hours of unpaid work than men do ( 24 vs. $17 \mathrm{~h}$ ). Therefore, I expect that the distribution of the capability to balance work with non-work, as well as the HBW impact on this capability, will be less gendered in Sweden than it is in Poland. Nevertheless, some authors argue, being a more gender-equal country than other European welfare states does not mean that Sweden is fully gender equal (Martinsson et al. 2016; see also Nyberg 2012; Rothstein 2012; Kaufman et al. 2017; Kusterer 2014). Therefore, I expect that in Sweden men in dual earner households will still be more capable than mothers but the difference between genders should be smaller than in Poland. ${ }^{3}$ Furthermore, because promoting gender equality does not mean that neither parent is engaged in housework and childcare, but rather that both are encouraged and expected to engage to a large extent in both, HBW

\footnotetext{
3 As the assessment of the difference between countries is made on the basis of two countries only, it is hard to formulate a strong hypothesis here.
} 
should have a similar, negative impact on the capability to engage in non-work activities for both Swedish mothers and fathers (Hypothesis 4).

\section{Data and Methods}

\subsection{Data}

As I argued in the previous section, standard time-use data may not account fully for the burden of household and childcare responsibilities, particularly in the context of HBW. For this reason, I turned to the Generations and Gender Survey, which provides internationally comparable and representative micro databases for both countries (the latest data for Poland are from 2014/2015, while for Sweden they are from 2012/2013). ${ }^{4}$ The survey also includes questions about engaging the respondent, in detail, about childcare- and housework-related tasks. The details of these variables and how they were used in this study can be found in the subsection: empirical specification of the model. Empirical analysis is based on a sample of working mothers and fathers (in Poland and Sweden, respectively) with dependent children (0-14 years old $)^{5}$ and living with partners (spouses) in double earner households. The subsample of working parents in Poland consists of 1855 respondents (917 men and 938 women) while the Swedish subsample comprised 974 respondents (441 men and 533 women); each respondent comes from a different household.

\subsection{Method}

There is a paucity of studies in the field that seek to measure the capability to balance work with non-work as a latent concept and simultaneously analyze its determinants. Studies that aim to measure the ability to balance work and family/life on the individual level rely on estimating traditional regression models of particular (separate) functionings (see e.g. Drobnic and Guillén Rodriguez 2011; Fagan and Walthery 2011), and therefore do not account for the latent and multidimensional nature of the capabilities. Sen (1999a) clearly distinguishes between what people are free/able to do and to be, i.e. their capabilities, from what they actually do and are, i.e. their particular functionings. However, the nature of the capabilities renders them nearly impossible to measure directly. The CA framework encourages one to search for methods to grasp these unobservable, latent constructs and not only rely on comparing separately and directly people's particular observable do-ings and be-ings. In this paper, I employ Structural Equation Modelling (SEM) to measure the

\footnotetext{
4 The variation in years of the data is only 1 year between countries and the phenomena analyzed (workload and the division of labour between parents) are not susceptible to rapid changes. Furthermore, neither Poland nor Sweden was suffering from a significant economic crisis at the time of the Survey. Thus, I do not expect the one-year difference in data collection to impact the results of this study. It must be stressed that the GGS is based on the same core questionnaire for all countries, in which GGS is carried out. All variables used in my study come from the core questionnaire and thus the results are comparable across countries.

5 The age limit has been imposed by the authors of the GGS for the section of the questionnaire about childcare responsibilities based on the assumption that older children do not need so much care as younger ones and thus do not generate the level of responsibility younger ones do.
} 
capability to balance work with non-work or, in other words, the capability to balance 'necessary work' with 'recreational labour' as an abstract, unobservable, latent construct.

SEM is particularly well suited to measuring capabilities because it links latent unobservable variables to observed ones and to measurement errors. These models allow for the use of multiple indicators of the capabilities analyzed, while at the same time quantifying the effects of covariates on individuals' capabilities. They also provide scores of the capabilities, which can be compared for subgroups, e.g. men and women. SEM enables the measurement of the capability to balance 'necessary work' with 'recreational labour' as a latent construct, compare the scores for this capability for men and women, and explore the differences in the impact of working from home on this capability across genders.

SEM provides estimates of the latent variables and includes exogenous 'causal' variables for the latent factors. As latent variables are not directly observable, they have an unknown measurement unit. Two methods are commonly used to set the metrics of the latent variables (Addabbo et al. 2014). The first consists in setting a parameter equal to 1 for each latent variable; hence, an observed indicator defines the measurement unit of the latent variable. The estimate derived from this methodology is referred to as an unstandardized solution. The second method consists in standardizing latent variables, setting their variance equal to 1 . This methodology leads to the 'standardized solution', which makes it easy to compare coefficients related to variables whose measurement unit is unknown, as we may refer to changes in standard deviations rather than to changes in obscure measurement units. However, the latter solution for endogenous latent variables may be recovered after estimation. In brief, for the model's identification I need to estimate the unstandardized parameters, which also provide the estimated standard errors and significance level of the coefficients, even though standardized coefficients are more easily comparable. For these reasons in this article I report both solutions. Once the parameters of the model are estimated, the latent variable scores (for the capability to balance work with non-work) for each individual can be calculated.

Previous papers that use SEM to estimate well-being within a CA framework include Kuklys (2005), Di Tommaso (2007), Krishnakumar (2007), Krishnakumar and Ballon (2008) and Addabbo et al. (2014). To the best of my knowledge, the capability to balance work with non-work has not yet been approached by the SEM framework yet.

\subsection{Empirical Specification of the Model}

I estimate a simple structural equation model comprising two parts: the measurement equation and the structural equation.

\subsubsection{The Measurement Equation}

In the first part, i.e. the measurement equation, the capability to balance work with nonwork is conceptualized as a latent, unobservable variable, and is measured with two indicators. For each of the indicators chosen to represent a latent construct, a weight (factor loading) is estimated. This weight represents how much that specific variable counts in explaining the latent variable relative to the other. For each covariate, its effect on the respondent's capability to balance 'necessary work' with 'recreational labour' is quantified.

The first indicator is the assessment of the respondent's burden with childcare responsibilities relative to the respondent's engagement in paid work. The second indicator is the 
Table 1 Rules for assigning level of relative burden with childcare tasks

\begin{tabular}{|c|c|c|}
\hline $\begin{array}{l}\text { Number of hours in paid work } \\
\left(\mathrm{h}_{\mathrm{pw}}\right)\end{array}$ & $\begin{array}{l}\text { Average level of responsibility with child- } \\
\text { care tasks }\left(\mathrm{r}_{\mathrm{a}}\right)\end{array}$ & $\begin{array}{l}\text { Assigned level of relative } \\
\text { burden with childcare } \\
\text { tasks }\end{array}$ \\
\hline \multirow[t]{4}{*}{$h_{\mathrm{pw}} \leq 15$} & $r_{a}=1$ & 1 (very high) \\
\hline & $1<\mathrm{r}_{\mathrm{a}}<1.5$ & 2 (high) \\
\hline & $1.5 \leq \mathrm{r}_{\mathrm{a}}<2$ & 3 (low) \\
\hline & $r_{a} \geq 2$ & 4 (very low) \\
\hline \multirow[t]{4}{*}{$15<\mathrm{h}_{\mathrm{pw}} \leq 30$} & $r_{a} \leq 1.5$ & 1 (very high) \\
\hline & $1.5<\mathrm{r}_{\mathrm{a}}<2$ & 2 (high) \\
\hline & $2 \leq \mathrm{r}_{\mathrm{a}}<2.5$ & 3 (low) \\
\hline & $r_{a} \geq 2.5$ & 4 (very low) \\
\hline \multirow{4}{*}{$30<h_{p w} \leq 45$} & $r_{a} \leq 2$ & 1 (very high) \\
\hline & $2<\mathrm{r}_{\mathrm{a}}<2.5$ & 2 (high) \\
\hline & $2.5 \leq \mathrm{r}_{\mathrm{a}}<3$ & 3 (low) \\
\hline & $r_{a} \geq 3$ & 4 (very low) \\
\hline \multirow[t]{4}{*}{$45<\mathrm{h}_{\mathrm{pw}} \leq 60$} & $r_{a} \leq 2.5$ & 1 (very high) \\
\hline & $2.5<\mathrm{r}_{\mathrm{a}}<3$ & 2 (high) \\
\hline & $3 \leq \mathrm{r}_{\mathrm{a}}<3.5$ & 3 (low) \\
\hline & $\mathrm{r}_{\mathrm{a}} \geq 3.5$ & 4 (very low) \\
\hline \multirow[t]{4}{*}{$h_{p w}>60$} & $r_{a} \leq 3$ & 1 (very high) \\
\hline & $3<\mathrm{r}_{\mathrm{a}}<3.5$ & 2 (high) \\
\hline & $3.5 \leq \mathrm{r}_{\mathrm{a}}<4$ & 3 (low) \\
\hline & $r_{a} \geq 4$ & 4 (very low) \\
\hline
\end{tabular}

The same rules were applied in case of the relative burden with housework tasks

assessment of the respondent's burden with housework responsibilities relative to respondent's engagement in paid work.

The extent to which the respondent is responsible for childcare related tasks in the household was derived from the answers to the question: I am going to read the various tasks that have to be done when one lives together with children. Please tell me, who in your household does these tasks? Choose your answer from the card. The childcare related routine/necessary tasks mentioned included: dressing children or seeing that the children are properly dressed; putting the children to bed or seeing that they go to bed; staying at home with the children when they are ill; helping the children with homework; taking the children to/from school, day care center, babysitter or leisure activities. The card shown to the respondent included the following answers: 1-always me; 2-usually me; 3-me and my partner about equally; 4-usually my partner or spouse; 5-always my partner or spouse; 6-usually another person. The last two answers were combined together (as 5) and then the answers were coded into the following five levels of responsibility for each relevant task: 1-it's entirely the respondent's responsibility, 2-it's mainly the respondent's responsibility, 3-it's shared equally between the respondent and his/her partner, 4-it is mainly the partner's (or another person's) responsibility, 5-it's the full responsibility of the partner (or another person). For each person, an average responsibility level was calculated from all four childcare tasks. Finally, in order to assess the respondent's burden with childcare responsibilities relative to respondent's engagement in paid work, the average responsibility 
level for childcare tasks was compared with the number of paid working hours for each respondent and one of four levels of the relative burden of childcare was assigned to each respondent: 1-denoting a very high childcare relative burden, 2-high childcare relative burden, 3-low childcare relative burden and 4-very low childcare relative burden. Table 1 presents exactly how these four level values were assigned to all respondents based on the average responsibility level for childcare tasks and number of hours in paid work. This way of assigning final values for this indicator was based on the following assumption/rule: the higher the engagement of the respondent in paid-work (measured in total hours of paid work per month) the lower must his/her responsibility for childcare be in order for her/him to maintain a high level of capability to balance work with non-work.

I respected the freedom of choice of a valued lifestyle (combination of the intensity of engagement in paid work and unpaid work) suggested within the framework of the capability approach. I likewise allow for a variety of arrangements over the shares of paid and unpaid work and do not value one over the other. For example, I assign a very high relative burden (1) of childcare to both mothers who generally entirely handle childcare responsibilities and work less than $15 \mathrm{~h}$ a week, and to mothers who say they share the childcare responsibilities whilst working more than $60 \mathrm{~h}$ a week (see Table 1). I evaluate the total burden of responsibilities based on the total amount of engagement in paid work and level of responsibility for childcare. Particularly, if a mother/father works full-time, she/he is not able to balance work with non-work if she/he is the only one (or the main person) responsible for childcare. In order to have a high level of capability to balance 'necessary work' with 'recreational labour', one's higher engagement in paid work must be accompanied (compensated) by lower responsibility for childcare tasks.

The second indicator was constructed in the same way as the first, but with reference to the question: Now I would like to ask you some questions about who does what in your household. Please tell me who does the following tasks in your household, choosing your answers from the card. The housework necessary/routine tasks included in the analysis were: preparing daily meals, doing the dishes, shopping for food, vacuum-cleaning the house, paying bills and keeping financial records. The card included the same answers as for the question about childcare. All further transformations of this variable into the second indicator were analogical to the transformations made for the first indicator (see Table 1). The descriptive statistics for both indicators in both countries are included in Table 2.

\subsubsection{The Structural Equation}

The structural equation linearly relates the latent capability variable to the explanatory variable(s). In the basic version of the model, I included the tested binary variable indicating whether the respondent, at least part of the week, works from home (1) or not (0) as well as the partner's (paid) workload (the total number of hours spent by the partner on paid work). The latter reflects the degree to which the respondent can share the paid-work with his/her partner (the more hours the partner spends on paid work, the less time he/she can offer in terms of unpaid work). One could argue that the more hours the respondent's partner works on the labour market, the higher the income-related opportunity to outsource (some of) the childcare and housework tasks outside the household would be. It must be noted, however, that most of the childcare/housework responsibilities this study considers (e.g. putting children to bed, dressing them or family book-keeping) are usually not outsourced. The binary variable for working at home was derived from the answers to the question: Which of the following statements best describes where you work? The answers 
Table 2 The descriptive statistics for all variables included in the models by country and gender

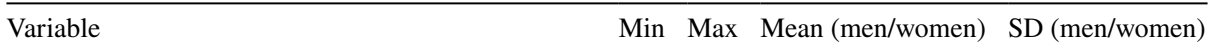

(a) Poland

$\begin{array}{lllll}\text { Measurement equation } & & & \\ \quad \text { Indicator 1 (childcare relative burden) } & 1 & 4 & 3.76 / 2.85 & 0.62 / 1.12 \\ \quad \text { Indicator 2 (housework relative burden) } & 1 & 4 & 3.59 / 2.41 & 0.78 / 1.12 \\ \text { Structural equation } & & & & \\ \text { Working from home } & 0 & 1 & 0.12 / 0.13 & 0.33 / 0.33 \\ \text { Partner's paid working hours (per week) } & 0 & 80 & 26.66 / 38.60 & 19.22 / 17.30 \\ \text { Number of children in the household } & 1 & 7 / 8 & 2.03 / 2.01 & 0.93 / 0.93 \\ \text { Age of the youngest child } & 0 & 14 & 6.10 / 6.27 & 4.28 / 4.16 \\ \text { Education of the respondent } & 1 & 3 & 1.93 / 2.29 & 0.83 / 0.76 \\ \text { Financial situation of the household } & 1 & 6 & 3.43 / 3.53 & 1.13 / 1.09 \\ \text { Attitude towards unpaid work relative to paid } & 1 & 5 & 2.89 / 2.84 & 0.91 / 0.93\end{array}$
work

(b) Sweden

$\begin{array}{lllll}\text { Measurement equation } & & & \\ \quad \text { Indicator 1 (childcare relative burden) } & 1 & 4 & 3.67 / 3.27 & 0.62 / 0.87 \\ \quad \text { Indicator 2 (housework relative burden) } & 1 & 4 & 3.29 / 2.99 & 0.86 / 0.97 \\ \text { Structural equation } & & & & \\ \quad \text { Working from home } & 0 & 1 & 0.12 / 0.13 & 0.32 / 0.34 \\ \text { Partner's paid working hours (per week) } & 0 & 80 & 36.64 / 42.85 & 8.64 / 7.74 \\ \text { Number of children in the household } & 1 & 6 / 5 & 2.08 / 2.12 & 0.77 / 0.76 \\ \text { Age of the youngest child } & 0 & 14 & 6.05 / 6.10 & 3.90 / 3.66 \\ \text { Education of the respondent } & 1 & 3 & 2.41 / 2.56 & 0.56 / 0.54 \\ \text { Financial situation of the household } & 1 & 6 & 4.58 / 4.63 & 1.05 / 0.99 \\ \text { Attitude towards unpaid work relative to paid } & 1 & 5 & 2.95 / 2.58 & 1.05 / 1.03 \\ \quad \text { work } & & & & \end{array}$

included: 1-I usually work in one place away from home, 2-I usually work at home, 3-I usually work part of the week at home and part away from home, 4-I usually work in a variety of places away from home. Answers 2 and 3 were recoded as 1 (I work from home), and answers 1 and 4 as 0 (I don't work from home).

The extended version of the model also includes other control variables including the number of children in the household, the age of the youngest child, the respondent's level of education (1-primary, 2-secondary or 3-tertiary), the household's financial situation and the respondent's attitude towards the value of the un-paid work compared to paid work. Household financial situation was determined from the answers to the question: A household may have different sources of income and more than one household member contribute to it. Thinking of your household's total monthly income, is your household able to make ends meet...1-with great difficulty, 2-with difficulty, 3-with some difficulty, 4-fairly easily, 5-easily, 6-very easily? The attitude towards un-paid work relative to paid work was determined from the question: To what extent do you agree with the following statement: Looking after home and family is just as fulfilling as working for pay. The responses included: 1-strongly agree, 2-agree, 3-neither agree nor disagree, 4-disagree, 5-strongly disagree. Table 2 presents the descriptive statistics for all variables included in the models 


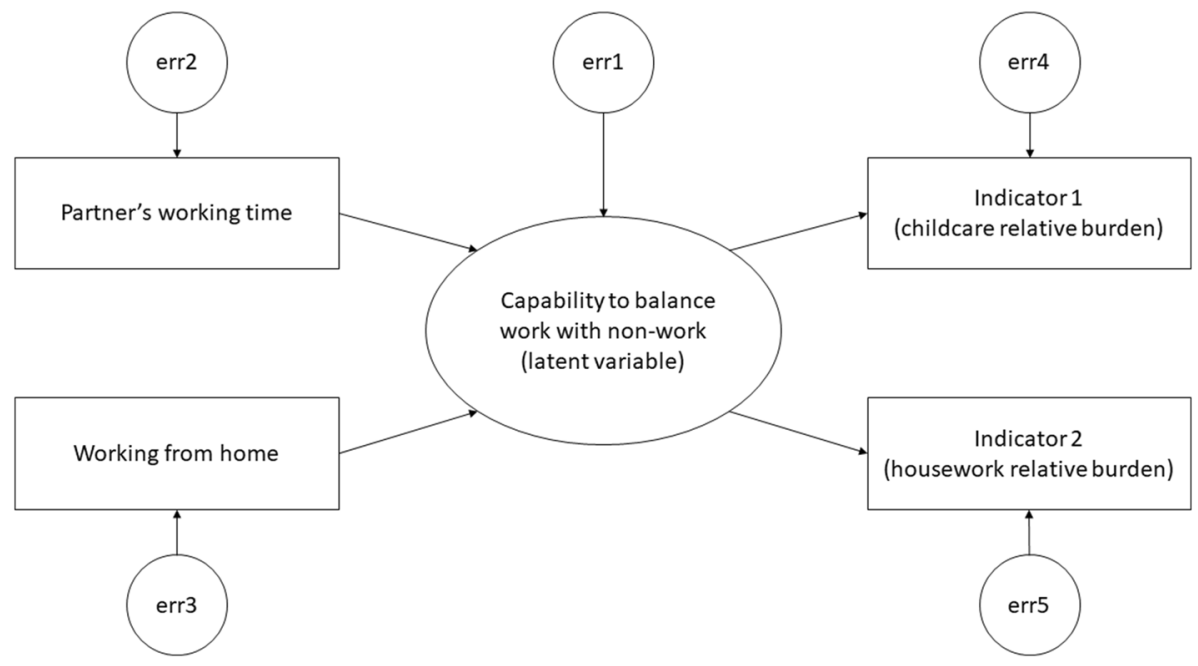

Fig. 1 The graphical presentation of the empirical specification of the basic version of the model

for both countries. Figure 1 presents, in graphic form, the structure of the entire model in its basic version.

\section{Results}

Tables $3 \mathrm{a}, \mathrm{b}$ and $4 \mathrm{a}, \mathrm{b}$ report the unstandardized and standardized parameters of the measurement model as well as unstandardized and standardized solutions for the capability to balance work with non-work for mothers (a) and fathers (b) in Poland and Sweden, respectively, for the basic and extended models. The results for the tested explanatory variableworking from home- are similar in both estimated models. I have also run sensitivity analyses with a slightly different scoring method for both indicators of the latent variable (not shown here); the conclusions from the analysis remain the same.

I find that the impact of home-based work on the capability to balance work with nonwork is significantly negative for mothers and fathers in Sweden, while in Poland the effect is significant only for mothers. This means that mothers in both countries, and fathers only in Sweden, who work from home at least part of the week, are on average less able to balance work with non-work (i.e. balance 'necessary work' with 'recreational labour') relative to mothers/fathers working outside the home. These results confirm the second and third hypotheses, namely that: (H2) in Poland HBW would be associated with lower capability to balance work with non-work among mothers, but not among fathers (H3). They also confirm the fourth hypothesis: in Sweden, the negative impact of HBW on the capability to balance work with non-work would be found among mothers as well as among fathers.

A comparison of the standardized coefficients from the basic model shows that the effect of working from home on the capability to balance work with non-work in Sweden 
Table 3 The results for measurement model and the structural equation of the capability to balance work with non-work for (a) mothers and (b) fathers of children up to 14 years old in Poland (GGS 2014/2015)

\begin{tabular}{lllll} 
Basic model & & & Extended model & \\
\cline { 1 - 2 } $\begin{array}{llll}\text { Unstandardized } \\
\text { coefficient (S.E.) }\end{array}$ & $\begin{array}{l}\text { Standard- } \\
\text { ized coef- } \\
\text { ficient }\end{array}$ & & $\begin{array}{l}\text { Unstandardized } \\
\text { coefficient (S.E.) }\end{array}$ & $\begin{array}{l}\text { Stand- } \\
\text { ardized } \\
\text { coeffi- } \\
\text { cient }\end{array}$
\end{tabular}

(a)

\begin{tabular}{|c|c|c|c|c|}
\hline \multicolumn{5}{|l|}{ Measurement model } \\
\hline Indicator 1 (childcare rel. burden) & $1(0)$ & 0.493 & $1(0)$ & 6.087 \\
\hline Indicator 2 (housework rel. burden) & $1.639 * * *(0.439)$ & 0.807 & 1. $01(0.092)$ & 0.065 \\
\hline \multicolumn{5}{|l|}{ Structural model } \\
\hline Working from home & $-0.259 * * *(0.087)$ & -0.157 & $-0.176^{*}(0.094)$ & -0.009 \\
\hline Partner's paid working hours & $-0.005 * * *(0.002)$ & -0.172 & $-0.003(0.008)$ & -0.007 \\
\hline Number of children & & & $0.067 * *(0.034)$ & 0.009 \\
\hline Age of the youngest child & & & $0.09 * * *(0.008)$ & 0.055 \\
\hline Education of the respondent & & & $0.092 * *(0.041)$ & 0.010 \\
\hline Financial sit. of the household & & & $-0.02(0.029)$ & 0.000 \\
\hline Attitude unpaid versus paid work & & & $-0.031(0.034)$ & -0.004 \\
\hline $\mathrm{N}$ & \multicolumn{2}{|l|}{938} & \multicolumn{2}{|l|}{938} \\
\hline Goodness of fit & \multicolumn{2}{|c|}{$\begin{array}{l}\text { TLI: 0.99; NFI: 0.99; RMSEA: } \\
0.01\end{array}$} & \multicolumn{2}{|c|}{$\begin{array}{l}\text { TLI: } 0.29 \text {; NFI: } 0.45 \text {; } \\
\text { RMSEA: } 0.08\end{array}$} \\
\hline
\end{tabular}

(b)

Measurement model

Indicator 2 (housework rel. burden)

0.679

$1(0)$

0.658

$1.105 * * *(0.353)$

0.770

$1.510 * * *(0.38)$

0.793

Structural model

Working from home

Partner's paid working hours

Number of children

Age of the youngest child

Education of the respondent

Financial sit. of the household

Attitude unpaid vs. paid work $\mathrm{N}$

$$
\begin{aligned}
& -0.076(0.058) \quad-0.052 \\
& -0.003^{* * *}(0.001) \quad-0.131 \\
& 917 \\
& \text { TLI: 0.99; NFI: 0.99; RMSEA: } \\
& 0.05
\end{aligned}
$$

$$
\begin{array}{ll}
-0.062(0.049) & -0.050 \\
-0.002 * *(0.001) & -0.106 \\
0.018(0.017) & 0.041 \\
-0.001(0.004) & -0.013 \\
-0.045 *(0.021) & -0.091 \\
-0.01(0.014) & -0.028 \\
0.040 *(0.019) & 0.090
\end{array}
$$

917

TLI: 0.29; NFI: 0.45; RMSEA: 0.08

$* * * p \leq 0.001 ; * * p \leq 0.05 ; * p \leq 0.1$

is stronger for fathers than for mothers. Furthermore, the impact of working from home on the capability to balance work with non-work is slightly stronger for Swedish mothers than for Polish mothers. These differences, however, are not statistically significant. ${ }^{6}$

\footnotetext{
${ }^{6}$ I compared the coefficients using a test suggested by Paternoster, Brame, Mazerolle and Piquero (1998).
} 
Table 4 The results for measurement model and the structural equation of the capability to balance work with non-work for (a) mothers and (b) fathers of children up to 14 years old in Sweden (GGS 2012/2013)

\begin{tabular}{llll} 
Basic model & & & Extended model \\
\cline { 1 - 1 } $\begin{array}{l}\text { Unstandardized } \\
\text { coefficient (S.E.) }\end{array}$ & $\begin{array}{l}\text { Standard- } \\
\text { ized coef- } \\
\text { ficient }\end{array}$ & $\begin{array}{l}\text { Unstandardized } \\
\text { coefficient (S.E.) }\end{array}$ & $\begin{array}{l}\text { Stand- } \\
\text { ardized } \\
\text { coeffi- } \\
\text { cient }\end{array}$ \\
\end{tabular}

(a)

$\begin{array}{lllll}\begin{array}{l}\text { Measurement model } \\ \text { Indicator 1 (childcare rel. burden) }\end{array} & 1(0) & 0.594 & 1(0) & 0.570 \\ \begin{array}{l}\text { Indicator 2 (housework rel. } \\ \text { burden) }\end{array} & 1.198^{* * *}(0.316) & 0.637 & 1.271^{* * *}(0.227) & 0.650 \\ \begin{array}{l}\text { Structural model } \\ \text { Working from home }\end{array} & -0.256^{* * *}(0.095) & -0.168 & -0.269^{* * *}(0.085) & -0.185 \\ \text { Partner's paid working hours } & -0.016^{* * *}(0.005) & -0.246 & -0.013^{* * *}(0.004) & -0.206 \\ \text { Number of children } & & & -0.063^{*}(0.037) & -0.096 \\ \text { Age of the youngest child } & & -0.035^{* * *}(0.008) & -0.259 \\ \text { Education of the respondent } & & 0.166^{* * *}(0.054) & 0.181 \\ \text { Financial sit. of the household } & & 0.055^{*}(0.028) & 0.110 \\ \text { Attitude unpaid versus paid work } & & 0.038(0.027) & 0.079 \\ \text { N } & 533 & 533 & \\ \text { Goodness of fit } & \text { TLI: } 0.98 \text {; NFI: 0.97; RMSEA: } & \text { TLI: } 0.51 \text {; NFI: } 0.57 ; & \\ & 0.02 & & \text { RMSEA: } 0.05 & \end{array}$

(b)

$\begin{array}{lllll}\begin{array}{l}\text { Measurement model } \\ \text { Indicator 1 (childcare rel. burden) }\end{array} & 1(0) & 0.650 & 1(0) & 0.468 \\ \begin{array}{c}\text { Indicator 2 (housework rel. } \\ \text { burden) }\end{array} & 1.225^{* *}(0.483) & 0.573 & 2.363^{* * *}(0.893) & 0.795 \\ \begin{array}{l}\text { Structural model } \\ \text { Working from home }\end{array} & -0.272^{* * *}(0.091) & -0.217 & -0.143^{* *}(0.069) & -0.158 \\ \text { Partner's paid working hours } & -0.003(0.003) & -0.055 & -0.001(0.002) & -0.045 \\ \text { Number of children } & & & 0.039(0.025) & 0.103 \\ \text { Age of the youngest child } & & 0.002(0.004) & 0.030 \\ \text { Education of the respondent } & & -0.075^{*}(0.038) & -0.145 \\ \text { Financial sit. of the household } & & 0.20(0.017) & 0.071 \\ \text { Attitude unpaid vs. paid work } & 441 & -0.011(0.016) & -0.040 \\ \text { N } & \text { TLI: } 0.99 ; \text { NFI: 0.99; RMSEA: } & \text { TLI: } 0.51 ; \text { NFI: } 0.57 ; \\ \text { Goodness of fit } & 0.01 & \text { RMSEA: } 0.05 \\ \end{array}$

$* * * p \leq 0.001 ; * * p \leq 0.05 ; * p \leq 0.1$

As expected, the results from the basic model show that for both mothers and fathers in Poland, their partner's time spent on paid work negatively and significantly affects the respondent's capability to balance 'necessary work' with 'recreational labour'. In Sweden, this effect is significant only for mothers. In the extended model, the significant effects hold except for Polish mothers. 


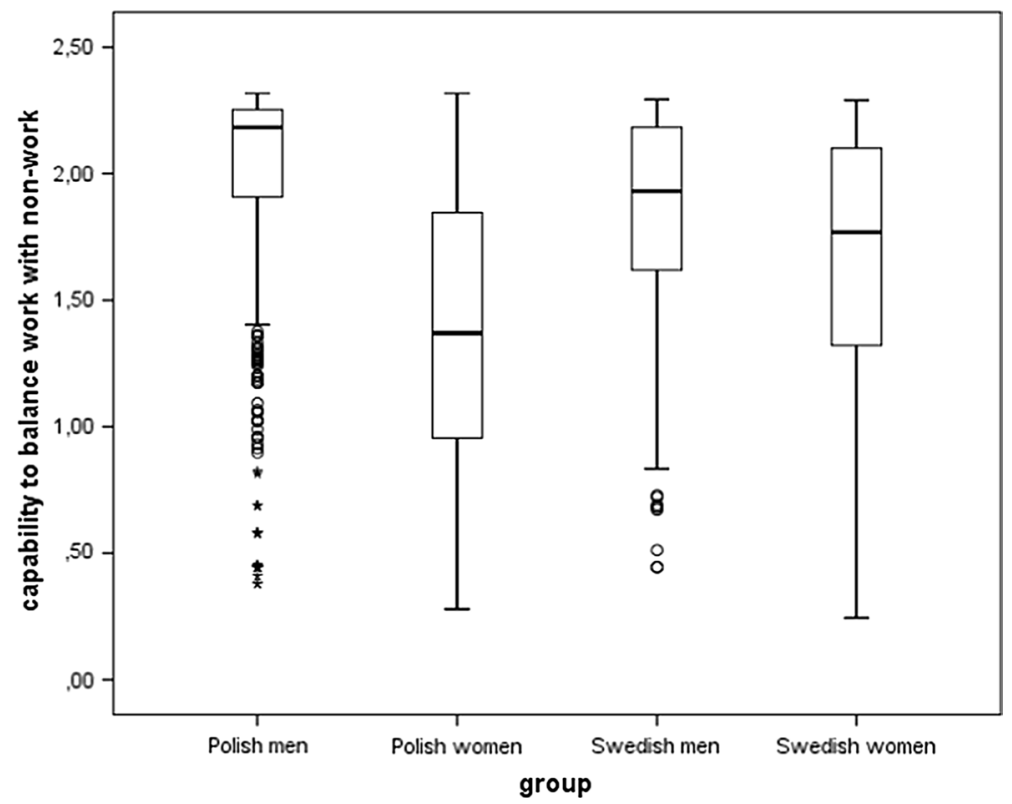

Fig. 2 Distribution of the imputed values for the latent variable-capability to balance work with nonwork-from the extended model for men and woman with children up to 14 years of age in the Polish and Swedish samples

The estimated structural equation model allows for the calculation of factor scores associated with the capability to balance work with non-work. The estimated factor scores can be further compared across genders and countries. ${ }^{7}$ The capability score values range between 0.24 and 2.32 (with mean equal to 1.71 and standard deviation equal to 0.54 ). The average level of the capability to balance 'necessary work' and 'recreational labour' in both countries is significantly higher for fathers than for mothers $(p \leq 0.01)$, although the difference between genders is visibly bigger for Poland. While the capability score for Polish fathers $(2.02)$ is significantly higher $(p \leq 0.01)$ than for Swedish fathers $(1.87)$, the capability score for Polish mothers $(1.36)$ is significantly $(p \leq 0.01)$ lower than for Swedish mothers (1.65). Figure 2 presents a comparison of the distributions of these scores among mothers and fathers in both countries based on the extended model. These results confirm H1: mothers in Poland will have lower capabilities than fathers (H1). Moreover, the difference in capabilities between genders is higher in Poland than in Sweden.

\footnotetext{
7 The AMOS software used in this study allows to estimate a joint model with split into four groups in order to compare the coefficients as well as calculated capability scores for mothers and fathers in both countries.
} 


\section{Discussion and Conclusion}

This study has contributed to the literature in two ways. First, it argues that gender sensitive WLB measurement should not only account for one's engagement in paid work, but also one's burden of housework and childcare responsibilities, i.e. the total burden of 'necessary work' (Ransome 2007). I therefore proposed a new analytical framework that accounts for the total burden of 'necessary work' in order to evaluate the capability of mothers and fathers to engage in non-work activities including sleep, leisure, self-care and relationships. The concept of 'capability' reflects having not only enough time, but also enough physical and psychical energy to engage in non-work activities while having a certain level of paid and un-paid work responsibilities. My study provides the first empirical attempt to apply Ransome's theoretical concept of 'total burden of responsibilities' in the study of balance between work and non-work activities. At the same time, it includes the application of the 'capability approach' proposed to the analysis of WLB by Hobson and others (Hobson 2014; Hobson et al. 2011; Yerkes and den Dulk 2015).

Second, I have applied the proposed framework to measure the impact of HBW on the capability to balance work and non-work in two countries with distinct division of labour models-Poland and Sweden. In Poland, women tend to be the primary carer, but also tend to be employed. Sweden is known for having one of the highest gender equality levels in Europe. Moreover, Swedish men have been encouraged to share the unpaid work with women for several decades. The results for Poland are in line with the 'exploitation model' (Huws et al. 1990; Sullivan and Lewis 2001; Hilbrecht et al. 2008; Kim 2018), according to which HBW perpetuates the gendered division of labour as women, in contrast to men, reallocate the 'saved time' from not having to commute, to caregiving or housework, instead of leisure. I have found that in Poland, HBW is significantly related to a lower capability to balance work with non-work among women only. Polish fathers, who are not expected to engage in childcare and housework, have been found to 'escape' the trap of the double burden of paid and unpaid work when working from home.

In Sweden, on the other hand, where both genders are expected to engage in housework and childcare, the negative effect of HBW on the capability to achieve WLB has been found among both genders. This sheds new light on the 'exploitation model' and shows that the negative impact of HBW on WLB may not be confined to women only. In a society in which men increasingly engage in childcare and housework duties, home-based work has similar effects on them as on women. Home-based work may enable workers to reconcile work and family (see e.g. Chung and Van der Horst 2018), but it does not provide more opportunity to engage in non-work activities, or as Ransome puts it, in 'recreational labour'. In other words, home based work should not be seen as a solution to increase one's balance between work and non-work but rather a measure for work-family reconciliation. However, while in gender egalitarian countries HBW enhances the possibilities for both men and women to engage more with family, in traditionally non-egalitarian countries it rather reinforces gender normative roles. This also implies that there might be significant differences in what HBW really is/means across genders and countries.

Finally, I have also compared the estimated levels of the capability to achieve WLB among men and women and found that in both countries mothers have lower capability then men, although the difference between genders is smaller in Sweden than in Poland. This finding is in line with Sweden being a more gender-equal country than Poland, though the traditional gender contract has not been entirely erased there (see also Martinsson et al. 2016; Nyberg 2012; Rothstein 2012; Kaufman et al. 2017; e.g. Kusterer 2014). 
Because the proposed approach to measuring the latent concept of capability to balance work with non-work among parents and the impact of home-based work on this capability is based on a simple Structural Equation Model and accessible data from the Generations and Gender Survey, it could be used in the future for a rich list of countries.

The above notwithstanding, this study has its shortcomings. First of all, the analysis was based on cross-sectional data, thus the results do not provide a basis for strong causal inferences. Second, while the Generations and Gender Survey database used for operationalizing the 'total burden of responsibilities' did provide detailed assessments of the share of the respondent in the responsibility for the various unpaid work tasks (several childcare and household duties), it did not provide a similar assessment of paid-work responsibilities. Therefore, I had to make this assessment based on the respondent's average number of working hours in the paid work. This resulted in different units of measurement for paid and unpaid work and therefore their being combined in an arbitrary manner in order to calculate the 'total burden of responsibilities'. More studies are needed in future, particularly on the level of responsibilities related to paid work. Furthermore, the indicators of the childcare/housework burden were based on treating different childcare/household tasks as contributing to the same extent to the value of the indicators. One could argue that some childcare responsibilities - staying at home with the children when they are sick, for example-are more burdensome than others e.g. dressing children or putting them to bed. The latter, however, may happen on a daily basis and therefore the average monthly burden due to both types of childcare tasks may actually be very similar. What could make a difference in the results of this study would be the significant differences in the distributions of particular tasks between mothers and fathers. However, these have not been addressed here. Nevertheless, the option of using particular weights for particular tasks could be considered in the future, and particularly for comparisons of the capabilities of different groups of mothers. Finally, this paper does not touch upon situations of "underemployment", which could also be considered as a non-balanced situation.

All in all this study has shown the importance of measuring the total burden of responsibilities resulting from all necessary work, i.e. paid and unpaid work, for the gender sensitive assessment of the impact of HBW on the capability to balance work with non-work activities.

Acknowledgements This article was written with financial support from the National Science Centre in Poland-Grant Number: 2014/13/D/HS4/03645. The author is grateful to Heejung Chung, Tanja Van der Lippe and two anonymous referees for their comments and suggestions.

Open Access This article is distributed under the terms of the Creative Commons Attribution 4.0 International License (http://creativecommons.org/licenses/by/4.0/), which permits unrestricted use, distribution, and reproduction in any medium, provided you give appropriate credit to the original author(s) and the source, provide a link to the Creative Commons license, and indicate if changes were made.

\section{References}

Addabbo, T., di Tommaso, M. L., \& Maccagnan, A. (2014). Gender differences in Italian children's capabilities. Feminist Economics, 20(2), 90-121.

Aguilera, A., Lethiais, V., Rallet, A., \& Proulhac, L. (2016). Home-based telework in France: Characteristics, barriers and perspectives. Transportation Reseach Part A, 90, 1-11.

Allard, K., Haas, L., \& Hwang, C. P. (2007). Exploring the paradox: Experiences of flexible working arrangements and work-family conflict among managerial fathers in Sweden. Community, Work and Family, 10(4), 475-493. 
Bianchi, S., Robinson, J., \& Milkie, M. (2006). Changing rhythms of american family life. New York: Sage.

Bradley, H., Healy, G., \& Mukherjee, N. (2005). Multiple burdens: Problems of WLB for ethnic trade union activist women. In D. M. Houston (Ed.), WLB in the 21st century (pp. 211-229). Basingstoke: Palgrave Macmillan.

Casper, J. W., Vaziri, H., Wayne, J. H., DeHauw, S., \& Greenhaus, J. (2017). The jingle-jangle of work-nonwork balance: A comprehensive and meta-analytic review of its meaning and measurement. Journal of Applied Psychology, 103(2), 182-214.

Chung, H., \& Van der Horst, M. (2018). Flexible working and unpaid overtime in the UK: The role of gender, parental and occupational status. Social Indicators Research. https://doi.org/10.1007/s1120 5-018-2028-7.

Chung, H., \& Van der Lippe, T. (2018). Flexible working, work life balance and gender equality: Introduction. Social Indicators Research. https://doi.org/10.1007/s11205-018-2025-x.

Ciccia, R., \& Bleijenbergh, I. (2014). After the male breadwinner model? Childcare services and the division of labor in European countries. Social Politics, 21(1), 50-79.

Clawson, D., \& Gerstel, N. (2014). Unequal time: Gender, class, and family in employment schedules. New York: Russell Sage Foundation.

Craig, L., \& Bittman, M. (2008). The incremental time costs of children: An analysis of children's impact on adult time use in Australia. Feminist Economics, 14(2), 57-85.

Craig, L., \& Sawrikar, P. (2009). Work and family: How does the (gender) balance change as children grow? Gender, Work and Organization, 16(6), 684-709.

Crosbie, T., \& Moore, J. (2004). Worklife balance and working from home. Social Policy and Society, 3(3), 223-233.

Di Tommaso, M. L. (2007). Measuring the well-being of children using a capability approach: An application to Indian data. Journal of Socio-Economics, 36, 436-450. https://doi.org/10.1016/j.socec .2006.12.006.

Drobnič, S., \& Guillén Rodriguez, A. (2011). Tensions between work and home: Job quality and working conditions in the institutional contexts of Germany and Spain. Social Politics, 18(2), 232-260.

Eurostat. (2017a). Statistical database (variable: lfst_hhwahchi) from: http://appsso.eurostat.ec.europa.eu/ nui/submitViewTableAction.do. Accessed January 1, 2018.

Eurostat. (2017b). 2017 Report on equality between women and men in the EU. https://doi. org/10.2838/52591.

Fagan, C., \& Walthery, P. (2011). Individual working-time adjustments between full-time and part-time working in European firms. Social Politics, 18(2), 269-299.

Fagan, J., \& Press, J. (2008). Father influences on employment Mothers' work-family balance. Journal of Family Issues, 29(9), 1136-1160.

Felstead, A., Jewson, N., Phizacklea, A., \& Walters, S. (2002). Opportunities to work at home in the context of work-life balance. Human Resource Management Journal, 12(1), 54-76.

Fleetwood, S. (2007). Re-thinking work-life balance: Editor's introduction. International Journal of Human Resource Management, 18(3), 351-359.

Gajendran, R. S., \& Harrison, D. A. (2007). The good, the bad, and the unknown about telecommuting: Meta-analysis of psychological mediators and individual consequences. Journal of Applied Psychology, 92(6), 1524-1541.

Gilligan, C. (1982). In a different voice: Psychological theory and women's development. Cambridge, MA: Harvard University Press.

Glover, J. (2002). The "balance model": Theorising women's employment behaviour. In A. Carling, S. Duncan, \& R. Edwards (Eds.), Analysing families. Morality and rationality in policy and practice (pp. 251-267). London: Routledge.

Gregory, A., \& Milner, S. (2009). Work-life balance: A matter of choice? Gender, Work and Organization, 16(1), 1-13.

Hartig, T., Kylin, C., \& Johansson, G. (2007). The telework tradeoff: Stress mitigation versus constrained restoration. Applied Psychology: An International Review, 56, 232-253.

Hilbrecht, M., Shaw, M. S., Johnson, L. C., \& Andrey, J. (2008). 'I'am home with kids: Contradictory implications for work-life balance of teleworking mothers. Gender, Work and Organization, 15(5), 454-476.

Hislop, D., \& Axtell, C. (2007). The neglect of spatial mobility in contemporary studies of work: The case of telework. New Technology, Work and Employment, 22(1), 34-51.

Hobson, B. (2014). Introduction: Capabilities and agency for work-life balance: A multidimensional framework. In B. Hobson (Ed.), Worklife balance. Agency and capabilities gap. Oxford: Oxford University Press. 
Hobson, B., \& Fahlen, S. (2009). Applying Sen's capabilities framework for work family balance within a European context: Theoretical and empirical challenges. REC-WP 03/2009. Working papers on the reconciliation of work and welfare in Europe.

Hobson, B., Fahlen, S., \& Takacs, J. (2011). Agency and capabilities to achieve work-life balance: A comparison of Sweden and Hungary. Social Politics, 18(2), 168-198.

Huws, U., Korte, W., \& Robinson, S. (1990). Telework: Towards the elusive office. Chichester: Wiley.

Kaufman, G., Bernhardt, E., \& Goldscheider, F. (2017). Enduring egalitarianism? Family transitions and attitudes toward gender equality in Sweden. Journal of Family Issues, 38(13), 1878-1898.

Kim, J. (2018). Workplace flexibility and parent-child interactions among working parents in the U.S. Social Indicators Research. https://doi.org/10.1007/s11205-018-2032-y.

Knudsen, K., \& Wærness, K. (2008). National context and spouses' housework in 34 countries. European Sociological Review, 24, 97-113.

Korpi, W., Ferrarini, T., \& Englund, S. (2013). Women's opportunities under different family policy constellations: Gender, class, and inequality tradeoffs in western countries re-examined. Social Politics, 20(1), 1-40.

Krishnakumar, J. (2007). Going beyond functionings to capabilities: An econometric model to explain and estimate capabilities. Journal of Human Development, 8(1), 39-63.

Krishnakumar, J., \& Ballon, P. (2008). Estimating basic capabilities: A structural equation model applied to Bolivia. World Development, 36(6), 992-1010.

Kuklys, W. (2005). Amartya Sen's capability approach: Theoretical insights and empirical applications. Berlin: Springer.

Kurland, N. B., \& Bailey, D. E. (1999). Telework: The advantages and challenges of working here, there, anywhere, and anytime. Organizational Dynamics, 28, 53-64.

Kurowska, A. (2013). Ocena zasadności założeń reformy urlopów i zasiłków związanych z opieką nad małym dzieckiem. Problemy Polityki Społecznej. Studia i Dyskusje, 21, 155-170.

Kusterer, H. (2014). Gender equality and liberal individualism: A critical reading of economist discourse in Sweden. Scandinavian Journal of Management, 30(3), 306-316.

Lewis, S. (2003). The integration of paid work and the rest of life. Is post-leisure work the new leisure? Leisure Studies, 22, 343-355.

Lott, Y. (2018). Does flexibility help employees switch off from work? Flexible working-time arrangements and cognitive work-to-home spillover for women and men in Germany. Social Indicators Research. https://doi.org/10.1007/s11205-018-2031-z.

Marsh, K., \& Musson, G. (2008). Men at work and at home: Managing emotion in telework. Gender, Work, and Organization, 15, 31-48.

Martinsson, L., Griffin, G., \& Nygren, K. G. (2016). Challenging the myth of gender equality in Sweden. Bristol: Policy Press University of Bristol.

Maruyama, T., Hopkinson, P. G., \& James, P. (2009). A multivariate analysis of work-life balance outcomes from a large-scale telework programme. New Technology, Work and Employment, 24, 76-88.

Mateyka, P. J., Rapino, M. A., \& Landivar, L. Ch. (2012). Home-based workers in the United States: 2010, US Census Bureau Report Number P70-132. Available at: https://www.census.gov/prod/2012pubs/ p70-132.pdf. Accessed 27 Nov 2018.

Mcdowell, L. (2004). Work, workfare, work/life balance and an ethic of care. Progress in Human Geography, 28, 145-163. https://doi.org/10.1191/0309132504ph478oa.

Mencarini, L., \& Sironi, M. (2010). Happiness, housework and gender inequality in Europe. European Sociological Review, 28(2), 203-219.

Milkie, M. A., \& Peltola, P. (1999). Playing all the roles: Gender and the work-family balancing act. Journal of Marriage and the Family, 61, 476-490.

Morganson, V. J., Major, D. A., Oborn, K., Vervie, J., \& Heelan, M. P. (2009). Comparing telework locations and traditional work arrangements. Journal of Managerial Psychology, 25(6), 578-595.

Nyberg, A. (2012). Gender equality policy in Sweden: 1970s-2010s. Nordic Journal of Working Life Studies, 2(4), 67-84.

Offer, S., \& Schneider, B. (2011). Revisiting the gender gap in time-use patterns: Multitasking and wellbeing among mothers and fathers in dual-earner families. American Sociological Review, 76, 809.

Paternoster, R., Brame, R., Mazerolle, P., \& Piquero, A. (1998). Using the correct statistical test for the equality of regression coefficients. Criminology, 36(4), 859-866.

Peters, P., Bleijenbergh, I., \& Oldenkamp, E. (2009). Cultural sources of variance in telework adoption in two subsidiaries of an ICT-multinational. International Journal of Employment Studies, 17(2), 66-101.

Pettinger, L., Parry, J., Taylor, R., \& Glucksmann, M. (2005). A new sociology of work?. Oxford: Wiley. 
Pichler, F. (2009). Determinants of work-life balance: Shortcomings in the contemporary measurement of WLB in large-scale surveys. Social Indicators Research, 92, 449-469.

Powell, A., \& Craig, L. (2015). Gender differences in working at home and time use patterns: Evidence from Australia. Work, Employment and Society, 29(4), 571-589. https://doi.org/10.1177/09500 17014568140.

Presser, H. (1994). Employment schedules among dual-earner partners and the division of household labour by gender. American Sociological Review, 59, 348-364.

Ransome, P. (2007). Conceptualizing boundaries between 'life' and 'work'. IJHRM, 18(3 March 2007), 374-386.

Rothstein, B. (2012). The reproduction of gender inequality in Sweden: A causal mechanism approach. Gender, Work and Organization, 19(3), 324-344.

Russell, H., O'Connell, P. J., \& McGinnity, F. (2009). The impact of flexible working arrangements on work-life conflict and work pressure in Ireland. Gender, Work and Organization, 16, 73-97.

Sen, A. (1999a). Commodities and capabilities. Oxford: Oxford University Press.

Sen, A. (1999b). Development as freedom. Oxford: Oxford University Press.

Silver, H. (1993). Homework and domestic work. Sociological Forum, 8(2), 181-204.

Sullivan, C., \& Lewis, S. (2001). Home-based telwork, gender and the synchronization of work and family: Perspectives of teleworkers and their co-residents. Gender, Work and Organization, 8(2), 123-145.

Taylor, R. (2002). The future of WLB?. Swindon: Economic and Social Research Council, ESRC Future of Work Programme.

Taylor, R. F. (2004). Extending conceptual boundaries: Work, voluntary work and employment. Work, Employment and Society, 18(1), 29-49.

Twigges, J. E., McQuillan, J., \& Ferree, M. M. (1999). Meaning and measurement: Reconceptualizing measures of the division of household labor. Journal of Marriage and Family, 61, 712-724.

Ungerson, C., \& Yeandle, S. (2005). Care workers and WLB: The example of domiciliary careworkers. In D. M. Houston (Ed.), WLB in the 21st century (pp. 246-262). Basingstoke: Palgrave Macmillan.

Van der Lippe, T., \& Lippényi, Z. (2018). Beyond formal access: Organizational context, working from home, and work-family conflict of men and women in European workplaces. Social Indicators Research. https://doi.org/10.1007/s11205-018-1993-1.

Voicu, M., Voicu, B., \& Strapcova, K. (2008). Housework and gender inequality in European countries. European Sociological Review, 25(3), 365-377.

Wheatley, D. (2012). Good to be home? Time-use and satisfaction levels among home-based teleworkers. New Technology, Work and Employment, 27(3), 224-241.

Wight, V. R., \& Raley, S. B. (2009). When home becomes work: Work and family time among workers at home. Social Indicators Research, 93(1), 197-202.

Yerkes, M. A., \& den Dulk, L. (2015). Arbeid-en-zorgbeleid in de participatiesamenleving. Tijdschrift Voor Arbeidsvraagstukken, 2015(31), 510-528.

Zick, C. D., \& Bryant, W. K. (1996). A new look at parents' time spent in child care: Primary and secondary time use. Social Science Research, 25, 260-280. 